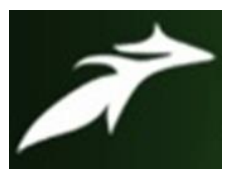

SENTIKUMZUK LONGKUMER et al, Int. Journal of Advances in Agricultural Science \& Technology, Vol.9 Issue.1, January-2022, pg. 14-21

ISSN: 2348-1358

\title{
TECHNOLOGICAL GAP IN RECOMMENDED CULTIVATION PRACTICES OF CABBAGE GROWERS AT KUHUBOTO BLOCK IN DIMAPUR DISTRICT OF NAGALAND
}

\author{
SENTIKUMZUK LONGKUMER ${ }^{1}$; Dr. D.K.BOSE ${ }^{2}$; Dr. JAHANARA ${ }^{3}$ \\ (M.Sc. Scholar); (Associate Professor); (Head of Department) \\ Department of Agricultural Extension \& Communication, \\ Sam Higginbottom University of Agriculture, Technology \& Sciences, Prayagraj (211007)
}

DOI: 10.47856/ijaast.2022.v09i01.002

\begin{abstract}
This study has been conducted to find out the technological gap in recommended cultivation practices of the cabbage growers in order to understand the extent of the difference between the traditional and non- traditional practices practiced by the local farmers in the district. The aforementioned study was conducted at Kuhuboto block in Dimapur district of Nagaland in the year 2021. A descriptive research designed was applied for this study. The primary data was collected from 120 respondents by personal interview method using prestructure interview schedule. After the analysis of the data, it was observed that, maximum number of the respondents (55.83\%) were having medium level of overall utilization of information sources and majority of the cabbage growers (62.50\%) belonged to medium level of over-all technological gap category. It indicates that a sum number of the population had incorporated the new technologies while others have still yet to adopt and use the new recommended cabbage cultivation. The socio- economic variables associated with the respondents, such as education and training exposure were positively significant with the extent of adoption of improved package of practices of cabbage cultivation. The above results compel the research and extension system to work on the gaps in a pragmatic way.
\end{abstract}

Keywords: Growers, Gap, Technological, Cabbage, Recommended 


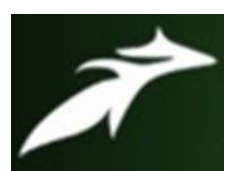

SENTIKUMZUK LONGKUMER et al, Int. Journal of Advances in Agricultural Science \& Technology, Vol.9 Issue.1, January-2022, pg. 14-21

ISSN: 2348-1358

Impact Factor: 6.846

NAAS Rating: 3.77

\section{Introduction}

Horticulture department in Nagaland has involved the policy of vegetable village programme during 2005-2006 under TM=NEH scheme and it is still continuing in all the successful villages. The state of Nagaland in general and Dimapur in particular had been gifted with a unique topography and varied agro-climatic and soil conditions, which offers opportunity to cultivate a variety of horticultural crops like vegetable and fruits. Among vegetables in spring/summer (cucurbit, bhindi beans etc) and in winter vegetables like (cabbage, cauliflower, carrot, radish, palak, pea, etc) are being cultivated in the districts. Fruits like guava, lemon, litchi and mango are the main major ones covering the area in districts. $20 \%$ of the area is covered with cabbage farming with a production of 40 metric tonnes.

\section{Method}

Descriptive research design was used for the present study, the major purpose of descriptive research is description of the state of affairs as it exists at present. Descriptive research design was followed, since the present study is fact-finding and present description of the respondents as well as the area. Multi stage sampling was followed for the present study for the selection of samples required. Kuhuboto block under Dimapur District has been selected purposively for the research work since it is one of the major districts in the State where cabbage cultivation is popularly practiced by the local farmers. There are 8 blocks in East Khasi Dimapur District out of which Kuhuboto Block was selected purposively because maximum area is under cabbage cultivation. The data was collected personally by the researcher through pre-tested interview schedules, discussion method. The primary data was collected with the help of interview schedule, designed especially in light of the objectives set up for the study. Secondary data was collected from available reports, journals, etc. Appropriate statistical tools was used for the study.

\section{Objectives of the study:}

1. To find out the socio-economic characteristics of the respondents.

2. To find out the extent of technological gap in recommended cultivation practices of the respondents. 


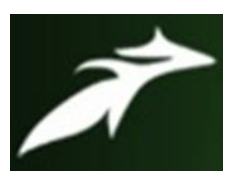

SENTIKUMZUK LONGKUMER et al, Int. Journal of Advances in Agricultural Science \& Technology, Vol.9 Issue.1, January-2022, pg. 14-21

ISSN: $2348-1358$

Impact Factor: 6.846

NAAS Rating: 3.77

\section{Review of Literature}

Bhagwan Sahay Yadav (2004) The main findings found that majority of the cauliflower growers had medium knowledge level about the recommended cultivation practices of cauliflower. Among the various aspects of different recommended cultivation practices, majority of the farmers had knowledge about "Recommended seed rate", "Recommended sowing time", "Name of recommended high yielding varieties", "Name of soil borne insect pests", "Name of the agencies to purchase the certified seeds", "Number of irrigations", "Duration of maturity of HYVs", "Transplanting time" and "Time of irrigations". Only a few farmers had knowledge regarding, "Quantity of weedicides", "Name of weedicides", "Time of spray of weedcide" and "Name of fungicide for seed treatment".

Kumar (2004) revealed that majority of the farmers had medium knowledge level about the recommended cultivation practices of cabbage. He also reported that most of farmers had knowledge about "Recommended seed rate", "Recommended sowing time", whereas only a few farmers had knowledge regarding "Storage practices", "Quantity of weedicide" and "Name of weedicide".

Shamsher and Singh(2014) carried out a study to know that the yield gaps between improved package of practices and existing farmers practice of cabbage. An average yield of cabbage in FLD ranged from 323.75-338.50 q/ha whereas in existing practice $250.00 \mathrm{q} / \mathrm{ha}$ in $2007-08$ and 2008-09. Percent increase yield with improved technology over existing practice was recorded in range of 29.50 to 35.40 . The extension gap ranging between $73.75-88.50 \mathrm{q} / \mathrm{ha}$ during the study period. The trend of technology gap reflected the farmer's cooperation, in carrying out such demonstrations with encouraging results in subsequent years. Average per hectare net profit was found Rs. 72,000.00 under demonstration while Rs. 42,600.00 under control. The benefit cost ratio was noticed 2.79 and 3.02 with demonstrations whereas 2.37 and 2.48 with farmers practices during 2007-08 and 2008-09, respectively. By conducting frontline demonstration of proven technologies, yield potential from cabbage cultivation can be enhanced to a great extent with increase in the income of the farmers.

Utpal Kant et al., (2019) The study revealed that majority of Cauliflower and Cabbage growers were of middle age group (42.5 percent), secondary \& higher secondary level education (45.00 percent), backward classes (45.00 percent), medium size of family (446.25 percent),marginal land holding (45.00percent), medium economic motivation (62.50 percent), medium level of market orientation (52.50percent), medium level of farm mechanization (56.25 percent), medium level of income (78.75 percent) and medium level of contact with extension agency (58.75 percent). 


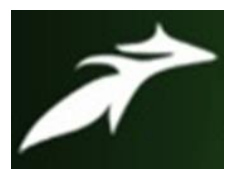

SENTIKUMZUK LONGKUMER et al, Int. Journal of Advances in Agricultural Science \& Technology, Vol.9 Issue.1, January-2022, pg. 14-21

ISSN: $2348-1358$

Impact Factor: 6.846

NAAS Rating: 3.77

Dheerendra et al. (2020) carried out a study in two district of Western Uttar Pradesh i.e. Meerut and Hapur to know the socio-economic profile of cabbage growers and correlation coefficients of socio-economic status with the knowledge and adoption. This study was done based on 200 respondents. The study revealed that the majority of cabbage growers $(59.00 \%)$ were belonged to middle age group, (54.50\%) belonged to Other Backward Caste, (22.50 and 22.50\%) respectively were having education up to 10th passed and intermediate level, $(90.00 \%)$ were married, $(73.50 \%)$ belonging to joint family system, $(64.00 \%)$ were having 5 to 8 members in family, (93.00\%) were having Pucca house, $(28.00 \%)$ respondents were having membership of only one social organizations, $(39.50 \%)$ were having 1 to 2 ha of land, most of the respondents earning income were between ₹ 1,00,001-2,00,000/- per annum and the majority of the respondents $(42.50 \%)$ were having medium level of socio-economic status in their society. The variable "Education" was found highly significant correlated with knowledge level moderate significant correlated with adoption level

\section{Results and Discussion}

It is therefore concluded from the study that the $60.83 \%$ of the respondents belonged to the age group of 39-60 years, $54.16 \%$ of the respondents were male, $65 \%$ of the respondents belonged to the family size of having 4-8 members, $67 \%$ of the respondents had nuclear family, $28.33 \%$ of the respondents were educated up to the level of middle school, $51.66 \%$ of the respondents had 1-2 ha land holdings, $61.66 \%$ of the respondents had annual income of ₹ 98717-₹ 244520 through cabbage cultivation, $68.33 \%$ of the respondents underwent training in the last 3 years, $23.33 \%$ of the respondents had more than 40 years of experience in cabbage cultivation and $55.83 \%$ of the respondents had medium overall use of information source in cabbage cultivation.

Table 1. Distribution of respondents based on overall utilization of information sources in cabbage cultivation.

\begin{tabular}{|l|l|c|c|}
\hline Sl. No. & $\begin{array}{l}\text { Level of utilization of information } \\
\text { sources }\end{array}$ & Frequency & Percentage \\
\hline 1 & Low $(<6.5)$ & 41 & 34.16 \\
\hline 2 & Medium (6.5- 9.3) & 67 & 55.83 \\
\hline 3 & High (>9.3) & 12 & 10 \\
\hline & Total & 120 & 100 \\
\hline
\end{tabular}

Mean=7.29, $\mathrm{SD}=1.72$ 


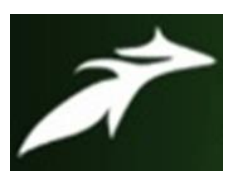

SENTIKUMZUK LONGKUMER et al, Int. Journal of Advances in Agricultural Science \& Technology, Vol.9 Issue.1, January-2022, pg. 14-21

ISSN: 2348-1358

Impact Factor: 6.846

NAAS Rating: 3.77

Table 1. Shows that 55.83 percent of the cabbage growers had medium level of utilization of information sources, while 34.16 percent of them had low utilization of information sources and 10 percent of them fell under the high category of overall information utilized.

Table 2. To understand the extent of technological gap in recommended cultivation practices of the respondents

\begin{tabular}{|c|c|c|c|}
\hline Sl. No. & $\begin{array}{c}\text { Areas of recommended } \\
\text { practices }\end{array}$ & $\begin{array}{c}\text { Average tech. gap } \\
(\%)\end{array}$ & Rank \\
\hline 1 & Variety & 69.33 & VI \\
\hline 2 & Soil & 69.79 & $\mathrm{~V}$ \\
\hline 3 & Climate & 49.16 & VIII \\
\hline 4 & Sowing time & 84.58 & IV \\
\hline 5 & Seed rate & 100 & $\mathrm{I}$ \\
\hline 6 & Seed treatment & 100 & $\mathrm{I}$ \\
\hline 7 & Field preparation & 34.16 & IX \\
\hline 8 & Spacing & 100 & I \\
\hline 9 & Nutrient management & 87.63 & II \\
\hline 10 & Mulching & 86.87 & III \\
\hline 11 & Irrigation & 100 & $\mathrm{I}$ \\
\hline 12 & Growth regulators & 100 & I \\
\hline
\end{tabular}




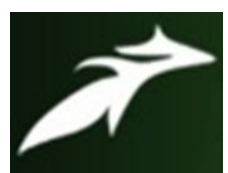

SENTIKUMZUK LONGKUMER et al, Int. Journal of Advances in Agricultural Science \& Technology, Vol.9 Issue.1, January-2022, pg. 14-21

ISSN: 2348-1358

Impact Factor: 6.846

NAAS Rating: 3.77

\begin{tabular}{|l|c|c|c|}
\hline 13 & Intercropping & 100 & I \\
\hline 14 & Insect-pest control & 100 & I \\
\hline 15 & Disease management & 100 & I \\
\hline 16 & Harvesting & 50 & VII \\
\hline 17 & Value added product & 100 & I \\
\hline
\end{tabular}

Table 2. shows that some of the recommended practices like seed rate, seed treatment, spacing, irrigation, growth regulators, inter-cropping, insect-pest control, disease management and value added products had an average technological gap percentage of 100 percent respectively making them rank $1^{\text {st }}$. Nutrient management had technological gap percentage of 87.63 percent ranking $2^{\text {nd }}$.Mulching ranked $3^{\text {rd }}$ with a technological gap of 86.87 percent. Sowing time ranked $4^{\text {th }}$ with technological gap percentage of 84.58 percent. Soil ranked $5^{\text {th }}$ with a technological gap of 69.79 percent. Recommended variety ranked $6^{\text {th }}$ with technological gap of 69.33 percent while harvesting ranked $7^{\text {th }}$ with a technological gap of 50 percent. Climate ranked $8^{\text {th }}$ with a technological gap of 49.16 percent. Field preparation ranked $9^{\text {th }}$ with a technological gap of 34.16 percent. 


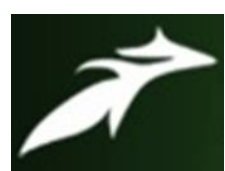

SENTIKUMZUK LONGKUMER et al, Int. Journal of Advances in Agricultural Science \& Technology, Vol.9 Issue.1, January-2022, pg. 14-21

ISSN: $2348-1358$

Impact Factor: 6.846

NAAS Rating: 3.77

Table 3. Distribution of the respondents based on the technological gap towards cabbage cultivation.

\begin{tabular}{|l|l|l|l|}
\hline S.No & Category & Frequency & Percentage \\
\hline 1 & Low $(<70.32)$ & 25 & 20.83 \\
\hline 2 & Medium (70.32- 74.60) & 75 & 62.50 \\
\hline 3 & High $(>74.60)$ & 20 & 16.66 \\
\hline & Total & 120 & 100.00 \\
\hline
\end{tabular}

Table 3 indicates that majority of the respondents 62.50 percent had medium level of technological gap followed by 20.83 percent and 16.66 percent respondents had low and high level of technological gap respectively. Distribution of more respondents in medium technological gap might be due to lack of knowledge about improved cabbage production technology.

Similar study was conducted by Utpal Kant et al (2019), a study on technological gap in production of cauliflowers and cabbage among growers of Patna district, and revealed that majority of the respondents had medium level of technology gap in practicing recommended cultivation practices of cauliflower and cabbage.

\section{Conclusion}

It is therefore concluded from the study that majority of the respondents fall under medium level of utilization of information sources and had medium level of technological gap. Further, the study also revealed that most of the respondents had infrastructural constraint like high decrease in price at harvesting time, lack of storage facilities, lack of electricity at the right time, lack of transportation and non-availability of seed/ seedling. Essential extension activities and special trainings should be organized frequently to enhance their knowledge level and also, efforts should be made to motivate the farmers to adopt more recommended package of practices of cabbage through conducting result demonstrations to highlight the benefits of recommended cultivation practices. 


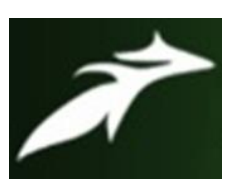

SENTIKUMZUK LONGKUMER et al, Int. Journal of Advances in Agricultural Science \& Technology, Vol.9 Issue.1, January-2022, pg. 14-21

ISSN: 2348-1358

Impact Factor: 6.846

NAAS Rating: 3.77

\section{References}

[1]. Bhagwan Sahay Yadav (2004) "Knowledge and adoption of improved cultivation practices of cauliflower by the farmers of govindgarh panchayat samiti of jaipur district of rajasthan" M. Sc. (Ag) Thesis, Rajasthan Agricultural University, Bikaner.

[2]. Kumar, M. (2004). "Adoption of improved cultivation practices of cabbage in Jaipur district of Rajasthan". M.Sc. (Ag.) Thesis, S.K.N. College of Agriculture, Jobner.

[3]. Shamsher, S., \& Singh, M. K. (2014). Impact of front line demonstration on cabbage (Brassica oleracea var. capitata L.) yield improvement in South Tripura. HortFlora Research Spectrum, 3(2), 158-161.

[4]. Utpal Kant, AK Paswan and Satyaprakash 2019. "Technological gap in production of cauliflower and cabbage among farmers of Patna District" M. Sc. (Ag) Thesis, RPCAU, Pusa, Samastipur, Bihar, India

[5]. Dheerendra Kumar, D. Kumar, Dan Singh, D. Singh, R. N. Yadav, R. N. Yadav, D. K. Singh, D. K. Singh, L. B. Singh, L. B. Singh, Manoj Kumar Singh, M. Kumar Singh, \& V. K. Singh, V. K. Singh. (2020). A study on cabbage growers in Western Uttar Pradesh. doi: 10.5958/2454-552X.2020.00010.9 